\title{
Chronic Pancreatitis—Update on Pathophysiology and Therapeutic Approaches
}

\author{
Chris J. C. ${ }^{1} \cdot$ Rowan W. Parks ${ }^{1}$ \\ Published online: 13 January 2020 \\ (C) The Author(s) 2020
}

\begin{abstract}
Chronic pancreatitis is an inflammatory condition characterized by structural change within the pancreas, that leads to progressive and irreversible loss of functioning pancreatic parenchyma, exocrine/endocrine dysfunction and an increased risk of pancreatic ductal adenocarcinoma. Whilst hallmarks of advanced disease are readily identifiable on routine clinical imaging, concordance between structural changes within the pancreas and symptoms is poor, such that early diagnosis can be challenging. Traditionally, chronic pancreatitis has been managed with a 'step-up' approach of measures including analgesia, therapeutic endoscopy and surgery (in a select minority of patients). Accumulating evidence is emerging to challenge this approach: early surgical intervention may offer the opportunity to interrupt the disease process before irreversible sequelae become established. This article provides an overview of the pathophysiology underlying chronic pancreatitis together with a review of the current evidence to support established and novel therapeutic approaches to the disease.
\end{abstract}

Keywords Chronic pancreatitis $\cdot$ Frey $\cdot$ Beger $\cdot$ Peustow $\cdot$ TPIAT

Chronic pancreatitis (CP) is a notoriously painful condition that is associated with considerable morbidity and increased mortality for affected patients. Traditionally, clinical management has revolved around escalation from conservative measures, through interventions for effective analgesia, endoscopic procedures and finally surgery as a last resort for a small minority of patients. Emerging evidence over the last decade suggests that this rationale may be flawed; surgical intervention for CP has been shown to be safe, effective and uniquely disease-modifying in comparison with other interventions, with early surgery showing the greatest benefit. This article provides an overview of the current understanding of pathophysiological processes underlying $\mathrm{CP}$, the treatment options available and a suggested therapeutic approach based on the available evidence.

Rowan W. Parks

R.W.Parks@ed.ac.uk

Chris J. C.

chris.johnston@ed.ac.uk

1 The University of Edinburgh, Edinburgh, UK

\section{Pathophysiology}

Recurrent acute pancreatitis is defined simply as more than one episode of inflammation of the pancreas. Chronic pancreatitis is a condition on the same spectrum of disease, but with the distinction of features of structural change within the pancreas, predominantly fibrosis, that leads to progressive and irreversible loss of functioning pancreatic parenchyma, exocrine/endocrine dysfunction and an increased risk of pancreatic ductal adenocarcinoma [1].

Excessive alcohol consumption is the primary risk factor for the development of $\mathrm{CP}$ and the most well-known, leading to a stigma associated with the disease that can further contribute to the patients' low quality of life scores [2]. However, it is clear that other factors including smoking, genetic mutations, metabolic disturbances and autoimmunity play a significant contribution in the aetiology of up to $50 \%$ of cases [3]. Further, although alcohol is responsible for most cases of CP, only a minority of alcoholics actually develop CP [4, 5]. The most widely accepted mechanistic model behind the development of $\mathrm{CP}$ is the 'Sentinel Acute Pancreatitis Event' hypothesis [6-8], whereby a single index or sentinel event of acute pancreatitis sensitizes the pancreas to further, more minor, inflammatory insults (e.g. alcohol or oxidative stress). Whilst alcohol has been shown to be directly toxic to the pancreatic ducts, acinar cells and microcirculation 
[9-11], repeated episodes of acute necrosis and inflammation lead to sensitization and persistent activation of the pancreatic stellate cells (PSCs) [5]. PSCs drive extracellular matrix collagen production, and their persistent activation explains why the fibrosis seen in CP is often considerably greater than might be expected from the cumulative damage of serial acute events alone.

Diagnosis of late-stage or advanced CP is usually straightforward, with a classical history, clinical features of pancreatic exocrine and endocrine failure, and signs of pancreatic fibrosis, atrophy and calcification on imaging. However, diagnosis of CP in the early stages of the disease (as distinct from recurrent acute pancreatitis) can be challenging, particularly as the extent of parenchymal damage and fibrosis often correlates very poorly with the clinical manifestations of exocrine dysfunction [12] and pain [13]. Given the poor concordance of pancreatic structure and function, the diagnosis of $\mathrm{CP}$ is based on a combination of clinical history, imaging, functional assessment and occasionally histology.

Whilst alcohol is not the only precipitant of $\mathrm{CP}$, the mechanisms behind its impact on the pancreas are comparatively well understood. Alcohol and its metabolites (including acetaldehyde) promote auto-digestion of the pancreatic acinar cells (through a combination of activating pro-enzymes, together with degradation of lysosome stability) and ongoing fibrosis by stimulation of the pancreatic stellate cells. These distinct processes lead to a number of clinically relevant manifestations. First, fibrosis leads to progressive stricturing and localized dilatation of the main pancreatic duct (Fig. 1). Stasis of pancreatic juice within the duct allows calculi to form and these can further contribute to an increased pressure within the gland, or 'parenchymal hypertension', which is thought to be one of the principal sources of pain in CP. Secondly, acinar cell necrosis stimulates a strong inflammatory response, leading to auto-digestion and persisting inflammation through positive feedback [14]. This can result in the development of a chronic inflammatory mass within the pancreas (almost invariably within the pancreatic head) and peripancreatic collections (pseudocysts).

Enlargement of the pancreatic head due to an inflammatory mass is present in approximately $30 \%$ of cases of CP [15]. This can act as a nidus of persisting inflammation propagating the disease process within the pancreas, and additional complications such as obstruction of the pancreatic duct and common bile duct. Pancreatic pseudocysts occur in up to $40 \%$ of patients with CP [16]. Intervention for drainage is indicated for persistent pain or if complications develop (in approximately 20\%), such as infection or symptomatic compression of adjacent structures $[17,18]$. Pseudocysts persisting for more than 6 months and greater than $5 \mathrm{~cm}$ in size should be drained, as they rarely resolve spontaneously and have been shown to develop complications in $41 \%$ of cases [18].

\section{Pain}

One of the primary difficulties encountered in the study of CP is the subjective feature of pain, as it is both the principle indication for treatment and the primary end point of the success or otherwise of any intervention [19]. Pain associated with $\mathrm{CP}$ is typically amongst the most severe of all chronic diseases with correspondingly dire quality of life scores [20]. However, the intensity of pain experienced by patients does not tend to correlate well with biochemical or radiological features of the disease [21], and objective quantification of the patient's symptoms is often inadequate.

The mechanisms of pain in CP are complex. Dilatation of the pancreatic duct indicative of ductal hypertension often coincides with severe pain, and interventions to decompress the duct (either endoscopic or surgical) have been shown to be effective in achieving symptomatic relief, at least in the short term [18]. However, endoscopic manometry measurements of pressure within the pancreatic duct correlate poorly with the degree of pain reported by patients [22], and sham intervention control groups are (understandably) lacking from clinical trial data. Interestingly, pancreatic enzyme replacement early in the course of CP has been shown to provide some pain relief and may therefore be indicated before the onset of clinically detectable exocrine insufficiency [23]. The mechanism behind this effect is as yet unclear. One hypothesis is that it may reduce the required exocrine production by the gland, or
Fig. 1 Classic CT appearances of chronic pancreatitis. a Axial and b coronal images showing pancreatic calcification, dilatation of the pancreatic duct and atrophy of parenchymal tissue. Images courtesy of Dr. David Cuete (Radiopaedia.org)

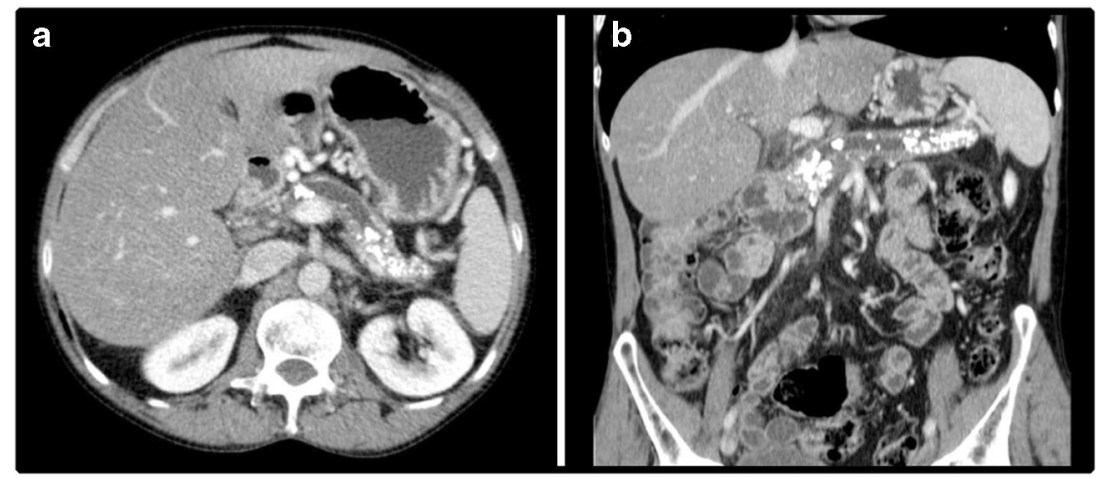


the pain experienced may be a secondary effect originating outside of the pancreas altogether [24].

Evidence of pathologically enhanced peripheral nociception secondary to CP has been demonstrated in both experimental animal models (e.g. enhanced sensory nerve excitability and upregulation of substance P) $[25,26]$ and in resected human pancreatic tissue (including neuritis and nerve hypertrophy) [27]. Central neuronal processing of painful stimuli has also been found to change over time, such that patients with longstanding $\mathrm{CP}$ have been shown to be more sensitive to unrelated exogenous painful stimuli [28].

At present, analgesic measures generally follow the WHOadvocated stepwise escalation from non-narcotic medications, through partial agonists, opiates, neuromodulating agents (e.g. pregabalin) to advanced techniques such as celiac plexus neurolysis [24]. However, the validity of this approach in the context of the specific pathophysiology of CP has been questioned [19]. Furthermore, analgesic measures alone, even if effective in controlling pain, should not replace, or delay, endoscopic or surgical intervention in the hope of spontaneous resolution [29]. Repeated objective assessment of symptoms is necessary so that failure of any intervention may be identified quickly, and escalation to more invasive measures can be instituted in a timely manner, to avoid needless progression of the disease process and establishment of complex pain syndromes with central sensitization.

\section{Endoscopic Interventions}

Endoscopy plays a fundamental role in the diagnosis of $\mathrm{CP}$ and in the management of several complications. Endoscopic ultrasound (EUS) is now considered the most sensitive investigation for diagnosing $\mathrm{CP}$, particularly in early stages of the disease [18, 30]. As the effectiveness of many therapeutic interventions, including surgery, are related to the time from onset of the disease process [29], this will likely become increasingly important in order to improve long-term outcomes in patients with early diagnostic uncertainty. Endoscopic retrograde cholangiopancreatography (ERCP) has now been superseded entirely as a diagnostic modality by magnetic resonance cholangiopancreatography (MRCP), but continues to play an important therapeutic role for the placement of stents and retrieval of ductal calculi.

ERCP is usually employed as the first-line intervention for removal of calculi from within the main pancreatic duct and this approach is supported by current clinical guidelines [31]. However, two recent randomised controlled trials have demonstrated surgical drainage of the pancreatic duct to be superior in terms of medium-long-term pain relief $[32,33]$. These findings are intuitively plausible - as discussed above, the formation of calculi in the main pancreatic duct tends to occur relatively late in the pathological process of $\mathrm{CP}$, i.e. pancreatic duct calculi form in the context of an already grossly abnormal and diseased organ. This is in contrast to, for example, gallstones forming within the gallbladder and migrating into a healthy and structurally normal bile duct. Endoscopic removal of pancreatic duct calculi can successfully treat acute symptoms or exacerbations due to obstruction, but rarely alters the underlying disease process of $\mathrm{CP}$ and therefore appears to exert limited benefit in the longer term. ERCP is also frequently used for treating dominant main pancreatic duct strictures (defined as strictures with upstream ductal dilatation of $\geq$ $6 \mathrm{~mm}$ [31]). Balloon dilation of strictures alone and shortterm stenting have generally yielded poor results [34]. Even with multiple ERCP procedures to allow for longer-term stent placement (with serial exchanges to avoid stent occlusion), the largest available study reported that severe pain recurred within 2 years of stent removal in $38 \%$ of patients [35].

\section{Surgical Drainage and Resection Procedures}

As previously discussed, pancreatic duct dilatation in $\mathrm{CP}$ is rarely due to a focal stenosis or solitary stone, but more often the result of extensive inflammation and fibrosis along the length of the duct [36]. Therefore, effective drainage can be achieved with a longitudinal pancreaticojejunostomy, whereby the anterior aspect of the pancreatic duct is opened along its length and then anastomosed in a side-to-side fashion with a Roux-en-Y reconstruction. This technique was first described by Puestow and Gillesby in 1958 [37] and later modified by Partington and Rochelle to preserve the pancreatic tail and spleen [38]. The 'modified Puestow' longitudinal pancreaticojejunostomy is currently the most commonly adopted surgical procedure when drainage of the pancreatic duct alone is required. It offers the advantages of preserving functioning pancreatic parenchymal tissue for exocrine and endocrine function with comparatively low postoperative mortality $(<4 \%)$ and morbidity rates $(6-19 \%)[39$, 40]. Successful relief of chronic pain is reported in over $90 \%$ of patients in the early post-operative period, but this rate declines with time, such that up to $40 \%$ of patients are readmitted for pain control and/or further procedures in the long term [39]. In these cases, recurrence of pain is often attributed to inflammation of the pancreatic head. This inflammatory process can contribute to recurrence of pancreatic (and biliary) obstruction, but is also thought to act as an origin or 'pacemaker' for persisting disease within the rest of the pancreas.

Where focal inflammation of the pancreatic head is the primary pathology, Whipple's pancreaticoduodenectomy (PD) or pylorus-preserving pancreaticoduodenectomy (PPPD) has traditionally been the surgical procedure of choice for patients fit enough for major surgery [41]. This approach is effective at consistently achieving pain relief in over $80 \%$ of patients and is particularly beneficial in situations where underlying malignancy cannot be excluded. However, many consider such a radical 
procedure (including resection of normal stomach, duodenum and bile duct) excessively aggressive for a benign inflammatory process. Resection of the pancreatic head with PD or PPPD also risks jeopardizing pancreatic function, with diabetes and/or symptomatic exocrine insufficiency reported in up to $50 \%$ of patients [42-44].

A more conservative, duodenum-preserving pancreatic head resection was introduced by Beger in 1972 [44]. This technique involves transection of the pancreas anterior to the portal vein and excision of the pancreatic head, leaving only a small remnant of pancreatic tissue adjacent to bile duct, followed by interposition of a Roux limb of jejunum as a pancreaticojejunostomy. Outcomes in terms of pain relief are similar to PD, and the avoidance of gastric and biliary anastomoses appears to translate into very low early post-operative morbidity [45]. However, long-term morbidity, mortality and pancreatic function are similar to $\mathrm{PD}$, and the Beger technique has not been adopted widely internationally [46].

The Frey procedure (Fig. 2) combines drainage of the main pancreatic duct by longitudinal pancreaticojejunostomy with (duodenum-preserving) partial pancreatic head resection by enucleation or 'coring out' of parenchymal tissue [47]. Early preservation of pancreatic glandular function compares favourably with other resectional techniques, but this benefit appears to be lost in the longer term [33].

A recent Cochrane Collaboration systematic review compared pancreaticoduodenectomy with duodenum-preserving pancreatic resection techniques (Frey, Beger and minor modifications) [48]. Five RCTs with a total of 269 patients were included. The quality of each study was classed as low due to a significant risk of bias. Duodenum-preserving techniques were shown to be associated with a marginally shorter hospital stay, but no statistically significant differences were demonstrated in mortality rates, quality of life, or incidence of post-operative diabetes or exocrine insufficiency.

\section{Total Pancreatectomy and Islet Autotransplantation}

Total pancreatectomy followed by digestion of the pancreas, isolation of islet cells and infusion into the patient's portal circulation is one radical surgical option that allows for preservation of glucose homeostasis without the need for the immunosuppression required of allogeneic islet transplants.

Current clinical guidance cites intractable pain severely impacting on the quality of life as a primary indication for total pancreatectomy and islet autotransplantation (TPIAT) [49]. The procedure is effective in achieving pain reduction or resolution [50] with a corresponding positive impact on the quality of life [51]. However, even after total pancreatectomy, severe pain does persist in a significant minority of patients (30\% still requiring narcotics at 1-year post-procedure and $7.5 \%$ reporting persistent pain similar to pre-operative levels) [52]. Failure of TPIAT to achieve resolution of pain appears to be multifactorial. Time for establishment of complex pain syndromes (e.g. central sensitization and opiate-induced hyperalgesia) has been implicated [53] and may account for the notable comparative success of the procedure in paediatric populations [50].

The risk of pancreatic ductal adenocarcinoma is increased in patients with chronic pancreatitis [54], but particularly so in cases of hereditary pancreatitis or predisposing genetic mutations $[55$, 56]. Distortion of the pancreatic parenchyma by inflammation and fibrosis in CP limits the capability of serial imaging to provide effective surveillance for malignancy and therefore, TPIAT may provide a valuable preventative option for the selected high-
Fig. 2 Frey procedure. a The pancreatic head is exposed and parenchymal tissue 'cored out', thereby preserving duodenum and bile duct. b The main pancreatic duct is opened along its length anteriorly. c, d A Roux limb of jejunum is brought up to complete the longitudinal pancreaticojejunostomy

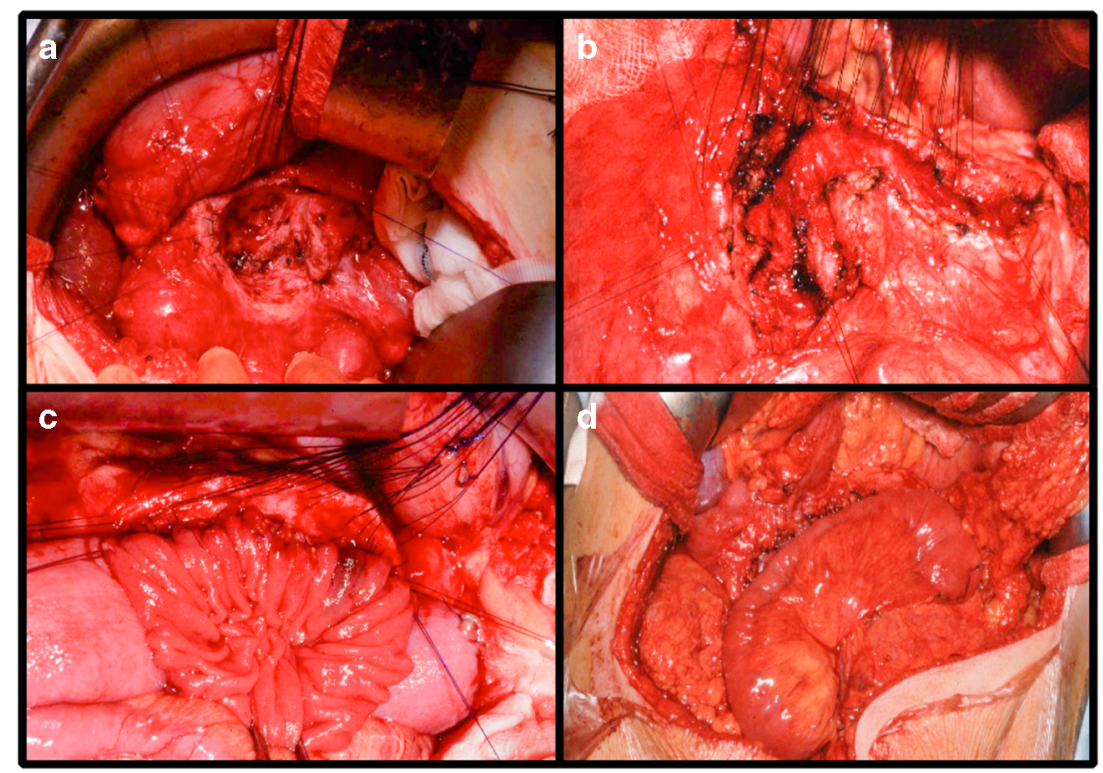


risk groups. No cases of post-TPIAT adenocarcinoma of pancreatic origin have been reported since the technique was introduced in 1977 [49, 57].

However, TPIAT is clearly a major undertaking with a number of inherent challenges and limitations. First, although islet autotransplantation preserves some islet endocrine function and thereby prevents the brittle diabetes associated with total pancreatectomy alone, insulin independence is only achieved in $25 \%$ of adult patient post-procedure [58]. Islet function is known to deteriorate over time [59], such that life-long surveillance for diabetes mellitus is required. Secondly, pancreatic exocrine function is entirely lost in all patients, necessitating life-long pancreatic enzyme replacement and placing patients at significant risk of new gastrointestinal adverse effects and fat-soluble vitamin deficiencies [60]. Thirdly, TPIAT entails splenectomy (which is not a feature of the other key surgical options for chronic pancreatitis), resulting in patients being at additional risk of sepsis from encapsulated bacteria and requiring life-long antibiotic prophylaxis. Finally, many of the factors predictive of a good outcome for TPIAT (such as short duration of narcotic use and absence of established complex pain syndromes) [52] are also associated with good outcomes for other, less invasive, surgical interventions for chronic pancreatitis. Previous pancreatic surgery represents a relative contraindication to TPIAT due to reduced islet yield [58] and therefore, selecting which patients with CP will benefit from the additional risks associated with TPIAT over traditional surgical options remains a challenge.

\section{Timing of Surgery}

Once CP is established, it is clear that loss of pancreatic parenchyma (and therefore function) is progressive [5], and ongoing severe pain from $\mathrm{CP}$ increases the risk of complex pain syndromes developing [61]. The most widely adopted clinical practice is a 'step-up' approach from conservative measures and analgesia, through endoscopic intervention, to surgery as a last resort [19]. However, this strategy has been challenged by two randomised controlled clinical trials comparing surgery for CP with endoscopic therapy $[32,62]$. Both studies have been criticised for study design, with a risk of bias and limited statistical power. However, their findings support early surgical intervention and challenge current clinical practice.

Cahen et al [32] randomised 39 patients with CP and distal obstruction of the pancreatic duct to surgical pancreaticojejunostomy or endoscopic treatment, with a primary end point being pain score [63]. Patients found to have an inflammatory mass in the head of the pancreas (who would intuitively derive greater benefit from surgery) were excluded from the study. Despite the relatively small number of patients included in the analysis, follow-up demonstrated a substantial reduction in pain scores for those randomised to the surgical group. The significant difference at an interim analysis $(p<0.001)$ resulted in recruitment to the study being terminated early by the overseeing safety committee. Despite this, the median follow-up time was 24 months, at which time effective pain relief had been achieved in $75 \%$ of patients in the surgery group, compared with only $32 \%$ in the endoscopy group ( $p=$ 0.007). In addition, patients in the endoscopy group underwent a significantly greater number of procedures, but with no difference in length of hospital stay or pancreatic exocrine function. This group published a further update after 5 years of follow-up and reported that not only did the endoscopy group undergo further procedures but also $47 \%$ of these patients eventually underwent surgery for symptom relief [33].

Interestingly, despite two further meta-analyses corroborating Cahen's findings in favour of surgery over endoscopic intervention [64, 65], translation to routine clinical practice, or acknowledgement in current clinical guidelines, has yet to happen. A further multi-centre randomised controlled trial comparing early surgery with the currently employed 'stepup' approach has recently completed recruitment and is due to report at the end of 2017 (the ESCAPE trial) [66]. The results of this study are keenly awaited. Until then, the currently available evidence would suggest that surgical intervention for CP should not be delayed unnecessarily.

\section{Conclusion}

Chronic pancreatitis is a complex condition requiring multifaceted care with a range of interventions from a variety of specialists. Despite many years of clinical experience and a wealth of experimental data, little long-term patient outcome data is available. The absence of conclusive randomised clinical trial data does not warrant dismissal of the accumulating evidence that is currently available to suggest that early surgical intervention may offer the benefits of more effective pain relief, reduced need for re-intervention and improved preservation of pancreatic function.

Open Access This article is licensed under a Creative Commons Attribution 4.0 International License, which permits use, sharing, adaptation, distribution and reproduction in any medium or format, as long as you give appropriate credit to the original author(s) and the source, provide a link to the Creative Commons licence, and indicate if changes were made. The images or other third party material in this article are included in the article's Creative Commons licence, unless indicated otherwise in a credit line to the material. If material is not included in the article's Creative Commons licence and your intended use is not permitted by statutory regulation or exceeds the permitted use, you will need to obtain permission directly from the copyright holder. To view a copy of this licence, visit http://creativecommons.org/licenses/by/4.0/. 


\section{References}

1. Kloppel G, Maillet B (1993) Pathology of acute and chronic pancreatitis. Pancreas 8(6):659-670

2. Gardner TB, Kennedy AT, Gelrud A, Banks PA, Vege SS, Gordon SR, Lacy BE (2010) Chronic pancreatitis and its effect on employment and health care experience: results of a prospective American multicenter study. Pancreas 39(4):498-501. https://doi.org/10. 1097/MPA.0b013e3181c5c693

3. Whitcomb DC, Yadav D, Adam S, Hawes RH, Brand RE, Anderson MA, Money ME, Banks PA, Bishop MD, Baillie J, Sherman S, DiSario J, Burton FR, Gardner TB, Amann ST, Gelrud A, Lo SK, DeMeo MT, Steinberg WM, Kochman ML, Etemad B, Forsmark CE, Elinoff B, Greer JB, O'Connell M, Lamb J, Barmada MM, North American Pancreatic Study G (2008) Multicenter approach to recurrent acute and chronic pancreatitis in the United States: the North American Pancreatitis Study 2 (NAPS2). Pancreatology : official journal of the International Association of Pancreatology 8(4-5):520-531. https://doi.org/10. $1159 / 000152001$

4. Steinberg W, Tenner S (1994) Acute pancreatitis. N Engl J Med 330(17):1198-1210. https://doi.org/10.1056/NEJM199404283301706

5. Witt H, Apte MV, Keim V, Wilson JS (2007) Chronic pancreatitis: challenges and advances in pathogenesis, genetics, diagnosis, and therapy. Gastroenterology 132(4):1557-1573. https://doi.org/10. 1053/j.gastro.2007.03.001

6. Aoun E, Muddana V, Papachristou GI, Whitcomb DC (2010) SPINK1 N34S is strongly associated with recurrent acute pancreatitis but is not a risk factor for the first or sentinel acute pancreatitis event. Am J Gastroenterol 105(2):446-451. https://doi.org/10. 1038/ajg.2009.630

7. Bartel M, Hansch GM, Giese T, Penzel R, Ceyhan G, Ketterer K, von Knebel-Doberitz M, Friess HM, Giese NA (2008) Abnormal crosstalk between pancreatic acini and macrophages during the clearance of apoptotic cells in chronic pancreatitis. J Pathol 215(2):195-203. https://doi.org/10.1002/path.2348

8. Whitcomb DC (2005) Genetic polymorphisms in alcoholic pancreatitis. Dig Dis 23(3-4):247-254. https://doi.org/10.1159/ 000090172

9. Vonlaufen A, Wilson JS, Pirola RC, Apte MV (2007) Role of alcohol metabolism in chronic pancreatitis. Alcohol research \& health : the journal of the National Institute on Alcohol Abuse and Alcoholism 30(1):48-54

10. Gukovskaya AS, Mouria M, Gukovsky I, Reyes CN, Kasho VN, Faller LD, Pandol SJ (2002) Ethanol metabolism and transcription factor activation in pancreatic acinar cells in rats. Gastroenterology 122(1):106-118

11. Grauvogel J, Grauvogel TD, Gebhard MM, Werner J (2012) Combined effects of chronic and acute ethanol on pancreatic injury and microcirculation. Pancreas 41(5):717-723. https://doi.org/10. 1097/MPA.0b013e318243a640

12. Bozkurt T, Braun U, Leferink S, Gilly G, Lux G (1994) Comparison of pancreatic morphology and exocrine functional impairment in patients with chronic pancreatitis. Gut 35(8):11321136

13. Chowdhury R, Bhutani MS, Mishra G, Toskes PP, Forsmark CE (2005) Comparative analysis of direct pancreatic function testing versus morphological assessment by endoscopic ultrasonography for the evaluation of chronic unexplained abdominal pain of presumed pancreatic origin. Pancreas 31(1):63-68

14. Thrower EC, Gorelick FS, Husain SZ (2010) Molecular and cellular mechanisms of pancreatic injury. Curr Opin Gastroenterol 26(5): 484-489. https://doi.org/10.1097/MOG.0b013e32833d119e

15. Zhao Y, Zhang J, Lan Z, Jiang Q, Zhang S, Chu Y, Wang C (2017) Duodenum-preserving resection of the pancreatic head versus pancreaticoduodenectomy for treatment of chronic pancreatitis with enlargement of the pancreatic head: systematic review and metaanalysis. Biomed Res Int 2017:3565438. https://doi.org/10.1155/ 2017/3565438

16. Barthet M, Bugallo M, Moreira LS, Bastid C, Sastre B, Sahel J (1993) Management of cysts and pseudocysts complicating chronic pancreatitis. A retrospective study of 143 patients. Gastroenterologie clinique et biologique 17(4):270-276

17. Jacobson BC, Baron TH, Adler DG, Davila RE, Egan J, Hirota WK, Leighton JA, Qureshi W, Rajan E, Zuckerman MJ, Fanelli R, Wheeler-Harbaugh J, Faigel DO, American Society for Gastrointestinal E (2005) ASGE guideline: the role of endoscopy in the diagnosis and the management of cystic lesions and inflammatory fluid collections of the pancreas. Gastrointest Endosc 61(3): 363-370

18. Lohr JM, Dominguez-Munoz E, Rosendahl J, Besselink M, Mayerle J, Lerch MM, Haas S, Akisik F, Kartalis N, IglesiasGarcia J, Keller J, Boermeester M, Werner J, Dumonceau JM, Fockens P, Drewes A, Ceyhan G, Lindkvist B, Drenth J, Ewald N, Hardt P, de Madaria E, Witt H, Schneider A, Manfredi R, Brondum FJ, Rudolf S, Bollen T, Bruno M, HaPan EUUEGWG (2017) United European Gastroenterology evidence-based guidelines for the diagnosis and therapy of chronic pancreatitis (HaPanEU). United European Gastroenterol J 5(2):153-199. https://doi.org/10.1177/2050640616684695

19. Windsor JA, Reddy ND (2017) Endoscopic vs. surgical interventions for painful chronic pancreatitis: what is needed for future clinical trials. Clinical and translational gastroenterology 8 (1): e213. doi:https://doi.org/10.1038/ctg.2016.68

20. Mullady DK, Yadav D, Amann ST, O’Connell MR, Barmada MM, Elta GH, Scheiman JM, Wamsteker EJ, Chey WD, Korneffel ML, Weinman BM, Slivka A, Sherman S, Hawes RH, Brand RE, Burton FR, Lewis MD, Gardner TB, Gelrud A, DiSario J, Baillie J, Banks PA, Whitcomb DC, Anderson MA, Consortium N (2011) Type of pain, pain-associated complications, quality of life, disability and resource utilisation in chronic pancreatitis: a prospective cohort study. Gut 60(1):77-84. https://doi.org/10.1136/gut.2010.213835

21. Wilcox CM, Yadav D, Ye T, Gardner TB, Gelrud A, Sandhu BS, Lewis MD, Al-Kaade S, Cote GA, Forsmark CE, Guda NM, Conwell DL, Banks PA, Muniraj T, Romagnuolo J, Brand RE, Slivka A, Sherman S, Wisniewski SR, Whitcomb DC, Anderson MA (2015) Chronic pancreatitis pain pattern and severity are independent of abdominal imaging findings. Clinical gastroenterology and hepatology : the official clinical practice journal of the American Gastroenterological Association 13(3):552-560; quiz e528-559. https://doi.org/10.1016/j.cgh.2014.10.015

22. Renou C, Grandval P, Ville E, Laugier R (2000) Endoscopic treatment of the main pancreatic duct: correlations among morphology, manometry, and clinical follow-up. International journal of pancreatology : official journal of the International Association of Pancreatology 27(2):143-149. https://doi.org/10.1385/JJGC:27:2:143

23. Slaff J, Jacobson D, Tillman CR, Curington C, Toskes P (1984) Protease-specific suppression of pancreatic exocrine secretion. Gastroenterology 87(1):44-52

24. Anderson MA, Akshintala V, Albers KM, Amann ST, Belfer I, Brand R, Chari S, Cote G, Davis BM, Frulloni L, Gelrud A, Guda N, Humar A, Liddle RA, Slivka A, Gupta RS, Szigethy E, Talluri J, Wassef W, Wilcox CM, Windsor J, Yadav D, Whitcomb DC (2016) Mechanism, assessment and management of pain in chronic pancreatitis: recommendations of a multidisciplinary study group. Pancreatology : official journal of the International Association of Pancreatology 16(1):83-94. https://doi.org/10. 1016/j.pan.2015.10.015

25. Winston JH, He ZJ, Shenoy M, Xiao SY, Pasricha PJ (2005) Molecular and behavioral changes in nociception in a novel rat 
model of chronic pancreatitis for the study of pain. Pain 117(1-2): 214-222. https://doi.org/10.1016/j.pain.2005.06.013

26. Liu L, Shenoy M, Pasricha PJ (2011) Substance P and calcitonin gene related peptide mediate pain in chronic pancreatitis and their expression is driven by nerve growth factor. JOP : Journal of the pancreas 12(4):389-394

27. Ceyhan GO, Bergmann F, Kadihasanoglu M, Altintas B, Demir IE, Hinz U, Muller MW, Giese T, Buchler MW, Giese NA, Friess H (2009) Pancreatic neuropathy and neuropathic pain-a comprehensive pathomorphological study of 546 cases. Gastroenterology 136(1):177-186 e171. https://doi.org/10.1053/j.gastro.2008.09.029

28. Di Sebastiano P, Fink T, Weihe E, Friess H, Innocenti P, Beger HG, Buchler MW (1997) Immune cell infiltration and growth-associated protein 43 expression correlate with pain in chronic pancreatitis. Gastroenterology 112(5):1648-1655

29. Yang CJ, Bliss LA, Schapira EF, Freedman SD, Ng SC, Windsor JA, Tseng JF (2014) Systematic review of early surgery for chronic pancreatitis: impact on pain, pancreatic function, and re-intervention. Journal of gastrointestinal surgery : official journal of the Society for Surgery of the Alimentary Tract 18(10):1863-1869. https://doi.org/10.1007/s11605-014-2571-8

30. Iglesias-Garcia J, Larino-Noia J, Lindkvist B, Dominguez-Munoz JE (2015) Endoscopic ultrasound in the diagnosis of chronic pancreatitis. Revista espanola de enfermedades digestivas : organo oficial de la Sociedad Espanola de Patologia Digestiva 107(4): 221-228

31. Dumonceau JM, Delhaye M, Tringali A, Dominguez-Munoz JE, Poley JW, Arvanitaki M, Costamagna G, Costea F, Deviere J, Eisendrath P, Lakhtakia S, Reddy N, Fockens P, Ponchon T, Bruno M (2012) Endoscopic treatment of chronic pancreatitis: European Society of Gastrointestinal Endoscopy (ESGE) Clinical Guideline. Endoscopy 44(8):784-800. https://doi.org/10.1055/s0032-1309840

32. Cahen DL, Gouma DJ, Nio Y, Rauws EA, Boermeester MA, Busch OR, Stoker J, Lameris JS, Dijkgraaf MG, Huibregtse K, Bruno MJ (2007) Endoscopic versus surgical drainage of the pancreatic duct in chronic pancreatitis. N Engl J Med 356(7):676-684. https://doi. org/10.1056/NEJMoa060610

33. Cahen DL, Gouma DJ, Laramee P, Nio Y, Rauws EA, Boermeester MA, Busch OR, Fockens P, Kuipers EJ, Pereira SP, Wonderling D, Dijkgraaf MG, Bruno MJ (2011) Long-term outcomes of endoscopic vs surgical drainage of the pancreatic duct in patients with chronic pancreatitis. Gastroenterology 141(5):1690-1695. https://doi. org/10.1053/j.gastro.2011.07.049

34. Nguyen-Tang T, Dumonceau JM (2010) Endoscopic treatment in chronic pancreatitis, timing, duration and type of intervention. Best Pract Res Clin Gastroenterol 24(3):281-298. https://doi.org/10. 1016/j.bpg.2010.03.002

35. Eleftherladis N, Dinu F, Delhaye M, Le Moine O, Baize M, Vandermeeren A, Hookey L, Deviere J (2005) Long-term outcome after pancreatic stenting in severe chronic pancreatitis. Endoscopy 37(3):223-230

36. Liu BN, Zhang TP, Zhao YP, Liao Q, Dai MH, Zhan HX (2010) Pancreatic duct stones in patients with chronic pancreatitis: surgical outcomes. Hepatobiliary \& pancreatic diseases international : HBPD INT 9(4):423-427

37. Puestow CB, Gillesby WJ (1958) Retrograde surgical drainage of pancreas for chronic relapsing pancreatitis. AMA archives of surgery 76(6):898-907

38. Partington PF, Rochelle RE (1960) Modified Puestow procedure for retrograde drainage of the pancreatic duct. Ann Surg 152: $1037-1043$

39. Adams DB, Ford MC, Anderson MC (1994) Outcome after lateral pancreaticojejunostomy for chronic pancreatitis. Ann Surg 219 (5): 481-487; discussion 487-489
40. Andersson R, Borjesson A, Blind PJ, Tingstedt B (2008) Pancreaticojejunostomy: a valid operation in chronic pancreatitis? Scand J Gastroenterol 43(8):1000-1003

41. Prinz RA (1993) Surgical options in chronic pancreatitis International journal of pancreatology : official journal of the International Association of Pancreatology 14(2):97-105. https:// doi.org/10.1007/BF02786115

42. Martin RF, Rossi RL, Leslie KA (1996) Long-term results of pylorus-preserving pancreatoduodenectomy for chronic pancreatitis. Arch Surg 131(3):247-252

43. Rumstadt B, Forssmann K, Singer MV, Trede M (1997) The Whipple partial duodenopancreatectomy for the treatment of chronic pancreatitis. Hepato-gastroenterology 44(18):1554-1559

44. Chiang KC, Yeh CN, Hsu JT, Chen HM, Chen HY, Hwang TL, Jan YY, Chen MF (2007) Pancreaticoduodenectomy versus Frey's procedure for chronic pancreatitis: preliminary data on outcome and pancreatic function. Surg Today 37(11):961-966. https://doi.org/ 10.1007/s00595-007-3539-z

45. Izbicki JR, Bloechle C, Knoefel WT, Kuechler T, Binmoeller KF, Broelsch CE (1995) Duodenum-preserving resection of the head of the pancreas in chronic pancreatitis. A prospective, randomized trial. Ann Surg 221(4):350-358

46. Bachmann K, Tomkoetter L, Erbes J, Hofmann B, Reeh M, Perez D, Vashist Y, Bockhorn M, Izbicki JR, Mann O (2014) Beger and Frey procedures for treatment of chronic pancreatitis: comparison of outcomes at 16-year follow-up. J Am Coll Surg 219(2):208-216. https://doi.org/10.1016/j.jamcollsurg.2014.03.040

47. Frey CF, Smith GJ (1987) Description and rationale of a new operation for chronic pancreatitis. Pancreas 2(6):701-707

48. Gurusamy KS, Lusuku C, Halkias C, Davidson BR (2016) Duodenum-preserving pancreatic resection versus pancreaticoduodenectomy for chronic pancreatitis. The Cochrane database of systematic reviews 2:CD011521. https://doi.org/10. 1002/14651858.CD011521.pub2

49. Bellin MD, Freeman ML, Gelrud A, Slivka A, Clavel A, Humar A, Schwarzenberg SJ, Lowe ME, Rickels MR, Whitcomb DC, Matthews JB, PancreasFest Recommendation Conference P, Amann S, Andersen DK, Anderson MA, Baillie J, Block G, Brand R, Chari S, Cook M, Cote GA, Dunn T, Frulloni L, Greer JB, Hollingsworth MA, Kim KM, Larson A, Lerch MM, Lin T, Muniraj T, Robertson RP, Sclair S, Singh S, Stopczynski R, Toledo FG, Wilcox CM, Windsor J, Yadav D (2014) Total pancreatectomy and islet autotransplantation in chronic pancreatitis: recommendations from PancreasFest. Pancreatology : official journal of the International Association of Pancreatology 14(1):27-35. https:// doi.org/10.1016/j.pan.2013.10.009

50. Bellin MD, Forlenza GP, Majumder K, Berger M, Freeman ML, Beilman GJ, Dunn TB, Pruett TL, Murati M, Wilhelm JJ, Cook M, Sutherland DE, Schwarzenberg SJ, Chinnakotla S (2017) Total pancreatectomy with islet autotransplantation resolves pain in young children with severe chronic pancreatitis. J Pediatr Gastroenterol Nutr 64(3):440-445. https://doi.org/10.1097/MPG. 0000000000001314

51. Morgan K, Owczarski SM, Borckardt J, Madan A, Nishimura M, Adams DB (2012) Pain control and quality of life after pancreatectomy with islet autotransplantation for chronic pancreatitis. Journal of gastrointestinal surgery : official journal of the Society for Surgery of the Alimentary Tract 16(1):129-133; discussion 133124. https://doi.org/10.1007/s11605-011-1744-y

52. Chinnakotla S, Beilman GJ, Dunn TB, Bellin MD, Freeman ML, Radosevich DM, Arain M, Amateau SK, Mallery JS, Schwarzenberg SJ, Clavel A, Wilhelm J, Robertson RP, Berry L, Cook M, Hering BJ, Sutherland DE, Pruett TL (2015) Factors predicting outcomes after a total pancreatectomy and islet autotransplantation lessons learned from over 500 cases. Ann 
Surg 262(4):610-622. https://doi.org/10.1097/SLA. 0000000000001453

53. Demir IE, Tieftrunk E, Maak M, Friess H, Ceyhan GO (2011) Pain mechanisms in chronic pancreatitis: of a master and his fire. Langenbeck's Arch Surg 396(2):151-160. https://doi.org/10.1007/ s00423-010-0731-1

54. Kirkegard J, Mortensen FV, Cronin-Fenton D (2017) Chronic pancreatitis and pancreatic cancer risk: a systematic review and metaanalysis. Am J Gastroenterol. https://doi.org/10.1038/ajg.2017.218

55. Rebours V, Boutron-Ruault MC, Schnee M, Ferec C, Maire F, Hammel P, Ruszniewski P, Levy P (2008) Risk of pancreatic adenocarcinoma in patients with hereditary pancreatitis: a national exhaustive series. Am J Gastroenterol 103(1):111-119. https://doi. org/10.1111/j.1572-0241.2007.01597.x

56. Ulrich CD, Consensus Committees of the European Registry of Hereditary Pancreatic Diseases MM-CPSGIAoP (2001) Pancreatic cancer in hereditary pancreatitis: consensus guidelines for prevention, screening and treatment. Pancreatology : official journal of the International Association of Pancreatology 1(5): 416-422

57. Najarian JS, Sutherland DE, Matas AJ, Goetz FC (1979) Human islet autotransplantation following pancreatectomy. Transplant Proc 11(1):336-340

58. Sutherland DE, Radosevich DM, Bellin MD, Hering BJ, Beilman GJ, Dunn TB, Chinnakotla S, Vickers SM, Bland B, Balamurugan AN, Freeman ML, Pruett TL (2012) Total pancreatectomy and islet autotransplantation for chronic pancreatitis. J Am Coll Surg 214(4): 409-424; discussion 424-406. https://doi.org/10.1016/j. jamcollsurg.2011.12.040

59. Kesseli SJ, Wagar M, Jung MK, Smith KD, Lin YK, Walsh RM, Hatipoglu B, Freeman ML, Pruett TL, Beilman GJ, Sutherland DE, Dunn TB, Axelrod DA, Chaidarun SS, Stevens TK, Bellin M, Gardner TB (2017) Long-term glycemic control in adult patients undergoing remote vs. local total pancreatectomy with islet autotransplantation. Am J Gastroenterol 112(4):643-649. https:// doi.org/10.1038/ajg.2017.14

60. Parsaik AK, Murad MH, Sathananthan A, Moorthy V, Erwin PJ, Chari S, Carter RE, Farnell MB, Vege SS, Sarr MG, Kudva YC (2010) Metabolic and target organ outcomes after total pancreatectomy: Mayo Clinic experience and meta-analysis of the literature.
Clin Endocrinol 73(6):723-731. https://doi.org/10.1111/j.13652265.2010.03860.x

61. Ahmed Ali U, Nieuwenhuijs VB, van Eijck CH, Gooszen HG, van Dam RM, Busch OR, Dijkgraaf MG, Mauritz FA, Jens S, Mast J, van Goor H, Boermeester MA, Dutch Pancreatitis Study G (2012) Clinical outcome in relation to timing of surgery in chronic pancreatitis: a nomogram to predict pain relief. Arch Surg 147(10):925932. https://doi.org/10.1001/archsurg.2012.1094

62. Dite P, Ruzicka M, Zboril V, Novotny I (2003) A prospective, randomized trial comparing endoscopic and surgical therapy for chronic pancreatitis. Endoscopy 35(7):553-558. https://doi.org/10. 1055/s-2003-40237

63. Bloechle C, Izbicki JR, Knoefel WT, Kuechler T, Broelsch CE (1995) Quality of life in chronic pancreatitis-results after duodenum-preserving resection of the head of the pancreas. Pancreas 11(1):77-85

64. Ahmed Ali U, Pahlplatz JM, Nealon WH, van Goor H, Gooszen HG, Boermeester MA (2015) Endoscopic or surgical intervention for painful obstructive chronic pancreatitis. The Cochrane database of systematic reviews 3:CD007884. https://doi.org/10.1002/ 14651858.CD007884.pub3

65. Jawad ZAR, Kyriakides C, Pai M, Wadsworth C, Westaby D, Vlavianos P, Jiao LR (2017) Surgery remains the best option for the management of pain in patients with chronic pancreatitis: a systematic review and meta-analysis. Asian J Surg 40(3):179185. https://doi.org/10.1016/j.asjsur.2015.09.005

66. Ahmed Ali U, Issa Y, Bruno MJ, van Goor H, van Santvoort H, Busch OR, Dejong $\mathrm{CH}$, Nieuwenhuijs VB, van Eijck $\mathrm{CH}$, van Dullemen HM, Fockens P, Siersema PD, Gouma DJ, van Hooft JE, Keulemans Y, Poley JW, Timmer R, Besselink MG, Vleggaar FP, Wilder-Smith OH, Gooszen HG, Dijkgraaf MG, Boermeester MA, Dutch Pancreatitis Study G (2013) Early surgery versus optimal current step-up practice for chronic pancreatitis (ESCAPE): design and rationale of a randomized trial. BMC Gastroenterol 13:49. https://doi.org/10.1186/1471-230X-13-49

Publisher's Note Springer Nature remains neutral with regard to jurisdictional claims in published maps and institutional affiliations. 